\title{
ANALISIS PENGEMBANGAN PLATFORM EKSPOR SUB SEKTOR KULINER TINJAUAN DARI MODEL SISTEM INOVASI
}

\author{
Sugeng Santoso ${ }^{1}$, Arfeo Natanael ${ }^{2}$, Ari Ana Fatmawati ${ }^{3}$, Ariela Griselda ${ }^{4}$, \\ Jeshica Khoirunnisa ${ }^{5}$ Martua Simanjuntak ${ }^{6}$, A. A. Raka Bagus ${ }^{7}$ \\ ${ }^{1}$ Magister Management Universitas Mercubuana, Jakarta, sugeng.santoso@mercubuana.ac.id \\ ${ }^{2}$ Magister Management Universitas Mercubuana, Jakarta, arfeonatanael94@gmail.com \\ ${ }^{3}$ Magister Management Universitas Mercubuana, Jakarta, ariana.aa66@gmail.com \\ ${ }^{4}$ Magister Management Universitas Mercubuana, Jakarta, arielagriselda@yahoo.com \\ ${ }^{5}$ Magister Management Universitas Mercubuana, Jakarta, jeshicaamalia@gmail.com \\ ${ }^{6}$ Magister Management Universitas Mercubuana, Jakarta, martua.simanjutntak@gmail.com \\ ${ }^{7}$ Ladang Lima, Surabaya, Indonesia, rakabagus@ladanglima.com
}

\begin{tabular}{ll|lll} 
Article history & \multicolumn{3}{l}{} \\
\hline Dikirim tanggal & $: 25 / 11 / 2020$ & Diterima tanggal & $: 06 / 03 / 2021$ \\
Revisi pertama tanggal & $: 10 / 03 / 2021$ & Tersedia online tanggal & $:$ & $20 / 03 / 2021$ \\
\hline
\end{tabular}

\begin{abstract}
ABSTRAK
Sektor ekonomi kreatif diharapkan mampu meningkatkan kontribusi Produk Domestik Bruto (PDB) sektor Ekonomi Kreatif (Ekraf), penyerapan tenaga kerja sektor Ekraf, jumlah usaha dan peningkatan ekspor produk atau jasa Ekraf. Ekonomi kreatif memiliki karakteristik yang berkaitan dengan rantai nilai dan nilai tambah yang mengandung kekayaan intelektual (Santoso, 2020). Pengembangan platform untuk pasar dalam negeri dan ekspor. Terdapat keterkaitan antara platform (intermediary side/ linkage) terhadap pelaku ekonomi kreatif (supply side) dan pemenuhan kebutuhan konsumen (demand side). Peningkatan kemampuan ekonomi berbasis ekonomi kreatif dilakukan melalui rekayasa ulang bisnis. Tujuan dari penelitian ini adalah menganalisis penataan ulang dari proses bisnis platform ekspor dibidang subsektor kuliner dengan menggunakan pendekatan model Sistem Inovasi yang merupakan keterkaitan sisi pasokan (supply), kebutuhan (demand) dan linkage (keterkaitan sisi supply dan demand).
\end{abstract}

Kata Kunci: Ekonomi Kreatif, Platform, Ekspor, Model Supply-Demand-Linkage

\section{ABSTRACT}

The creative economy sector is expected to increase the contribution of Gross Domestic Product $(G D P)$ in the Creative Economy sector (Ekraf), the absorption of labor in the Ekraf sector, the number of businesses and the increase in exports of Ekraf products or services. The creative economy has characteristics related to value chains and added value that contain intellectual property (Santoso, 2020). Development of platforms for domestic and export markets. There is a connection between the platform (intermediary side / linkage) to the creative economic actors (supply side) and the fulfillment of consumer needs (demand side). The improvement of economic capabilities based on creative economy is done through business re-engineering. The purpose of this study is to analyze the reorganization of the business process of export platforms in the field of culinary subsectors by using the innovation system model approach which is supply-side interrelationship, demand and linkage (supply and demand side interrelationship).

Keywords: Creative Economy, Platform, Export, Supply Model-Demand-Linkage 


\section{PENDAHULUAN}

Istilah 'ekonomi kreatif' pertama kali diperkenalkan oleh John Howkins melalui bukunya "The Creative Economy: How People Make Money from Ideas". Terdorong oleh perubahan paradigma ekonomi di tahun 1997, dimana HKI menjadi barang ekspor nomor satu di Amerika Serikat. John Howkins menyadari akan lahirnya era ekonomi baru yang berbasis pada kreativitas manusia dan mendefinisikan ekonomi kreatif sebagai "The creation of values as a result of idea". Karakter ekonomi kreatif dicirikan dari aktivitas ekonomi yang bertumpu pada eksplorasi dan eksploitasi ide-ide kreatif yang memiliki nilai jual tinggi. Ekonomi kreatif merupakan sebuah era baru ekonomi yang mengintensifkan informasi dan kreativitas dengan mengandalkan ide dan pengetahuan dari sumber daya manusia sebagai faktor produksi utama dalam kegiatan ekonomi. Sektor ekonomi kreatif diharapkan mampu meningkatkan kontribusi Produk Domestik Bruto (PDB) sektor Ekonomi Kreatif (Ekraf), penyerapan tenaga kerja sektor Ekraf, jumlah usaha dan peningkatan ekspor produk atau jasa Ekraf. Ekonomi kreatif memiliki karakteristik yang berkaitan dengan rantai nilai dan nilai tambah yang mengandung kekayaan intelektual (Santoso, 2020).

Realisasi pertumbuhan PDB ekonomi kreatif pada tahun 2019 adalah 96.23\% dari target, realisasi penyerapan tenaga kerja mencapai $110.52 \%$ dari target, sedangkan realisasi nilai ekspor bruto sebesar $102,65 \%$ dari target.

Tabel 1. Capaian Kinerja Sektor Ekonomi Kreatif Tahun 2019

\begin{tabular}{cllccc}
\hline No & \multicolumn{1}{c}{ Sasaran Strategis } & \multicolumn{1}{c}{$\begin{array}{c}\text { Indikator Kinerja Sasaran } \\
\text { Strategis }\end{array}$} & Target & Realisasi & $\begin{array}{c}\text { Capaian } \\
(\%)\end{array}$ \\
\hline 1. & $\begin{array}{l}\text { Pertumbuhan ekonomi } \\
\text { kreatif }\end{array}$ & $\begin{array}{l}\text { Pertumbuhan PDB Ekonomi } \\
\text { kreatif (\%) }\end{array}$ & 5.30 & 5.10 & 96.23 \\
2. & $\begin{array}{l}\text { Penyerapan tenaga } \\
\text { kerja }\end{array}$ & $\begin{array}{l}\text { Serapan Tenaga kerja (juta } \\
\text { orang) }\end{array}$ & 17.20 & 19.01 & 110.52 \\
3. & $\begin{array}{l}\text { Nilai Ekspor produk } \\
\text { kreatif }\end{array}$ & $\begin{array}{l}\text { Nilai ekspor bruto (Miliar } \\
\text { USD) }\end{array}$ & 21.50 & 22.07 & 102.65 \\
\hline
\end{tabular}

Sumber: Badan Ekonomi Kreatif, 2020

Kuliner merupakan salah satu sub sektor ekonomi kreatif yang perlu dikembangkan, sebagaimana tercantum dalam Perpres 142 Tahun 2018 tentang Rencana Induk Pengembangan Ekonomi Kreatif (Rindekraf) Nasional Tahun 2018-2025 (pasal 6). Dari ke-16 sub sektor ekonomi kreatif lainnya, kuliner merupakan sub sektor ekonomi kreatif yang memberikan kontribusi terbesar bagi Produk Domestik Bruto (PDB) Ekonomi Kreatif. Data statistik yang dirilis oleh BPS tahun 2017 bahwa hasil survei ekonomi kreatif di sub sektor kuliner memberi sumbangan sebesar 41,4\% dari 922,59 triliun terhadap PDB Ekonomi Kreatif, menyerap hingga 47,21\% dari 16,91 juta tenaga kerja ekonomi kreatif, serta berkontribusi menyumbang ekspor sebesar 6,31\% dari US\$ 20 miliar (data BPS 2016). Selanjutnya, berdasarkan data yang diperoleh dari Badan Ekonomi Kreatif (Bekraf) diketahui bahwa kontribusi kuliner tahun 2017 sebesar 44,55\% dan tahun 2018 diprediksikan sebesar 44,78\% (hasil proyeksi BPPT dan Bekraf). Berdasarkan data tersebut dengan menyumbang lebih dari $40 \%$ maka industri kuliner mempunyai potensi yang sangat kuat untuk berkembang. 
Indonesia merupakan negara yang terdiri dari ribuan pulau, kekayaan rempah yang melimpah, dengan ragam suku bangsa dan budaya. Kondisi ini perlu dimanfaatkan dalam proses pengembangan kuliner Indonesia. Potensi kuliner Indonesia untuk berkembang, baik di tanah air maupun mancanegara, perlu mendapat perhatian khusus dari segenap masyarakat Indonesia, baik pemerintah, pelaku usaha kuliner, mitra pelaku usaha, akademisi, komunitas/asosiasi, media, dan pihak-pihak terkait lainnya. Oleh karena itu, setiap pemangku kepentingan perlu bersinergi membantu kuliner Indonesia agar dapat menguasai pasar lokal dan mancanegara.

Pengembangan platform untuk pasar dalam negeri dan ekspor serta iklan perlu mendapat perhatian. Penelitian yang dilakukan Dewi RD dkk (2020) menyatakan bahwa iklan ternyata meningkatkan pendapatan kunjungan sampai $74 \%-150 \%$, sehingga dapat dikatakan periklanan merupakan aktifitas ekonomi kreatif yang memiliki nilai tambah yang cukup besar. Riset Lira dkk (2020) mengalisis korelasi antara keberadaan komunitas (intermediary side) terhadap inovasi pelaku ekonomi kreatif (supply side) dan pemenuhan kebutuhan konsumen (demand side). Indikator yang menandakan bahwa kemampuan memenuhi pesanan pelanggan suatu perusahaan dalam pengiriman barang adalah nilai Perfect Order Fulfillment (POF) yang besar. Semakin besar nilai POF yang dimiliki suatu perusahaan maka semakin baik kemampuan perusahaan dalam memenuhi kebutuhan pelanggan (Santoso dkk, 2020). Peningkatan kemampuan ekonomi berbasis ekonomi kreatif dilakukan melalui rekayasa ulang bisnis (Giri and Santoso, 2020). Tujuan dari penelitian ini adalah menganalisis penataan ulang dari proses bisnis platform ekspor dibidang subsektor kuliner dengan menggunakan pendekatan model Sistem Inovasi yang merupakan keterkaitan sisi pasokan (supply), kebutuhan (demand) dan linkage (keterkaitan sisi supply dan demand).

\section{KAJIAN LITERATUR}

\section{Kuliner}

Barang kuliner yang dimaksud dalam ruang lingkup subsektor kuliner adalah produk pengolahan makanan dan minuman yang pada umumnya berupa produk dalam kemasan- specialty foods. Produk ini berbeda dengan barang olahan makanan dan minuman reguler. Specialty foods memiliki keunikan dibandingkan dengan barang regular. Menurut Klasifikasi Baku Lapangan Usaha Indonesia (KBLI) Sektor Ekonomi Kreatif, sub sektor kuliner memiliki 31 subsektor/kategori (Ari Ana dan Santoso, 2020).

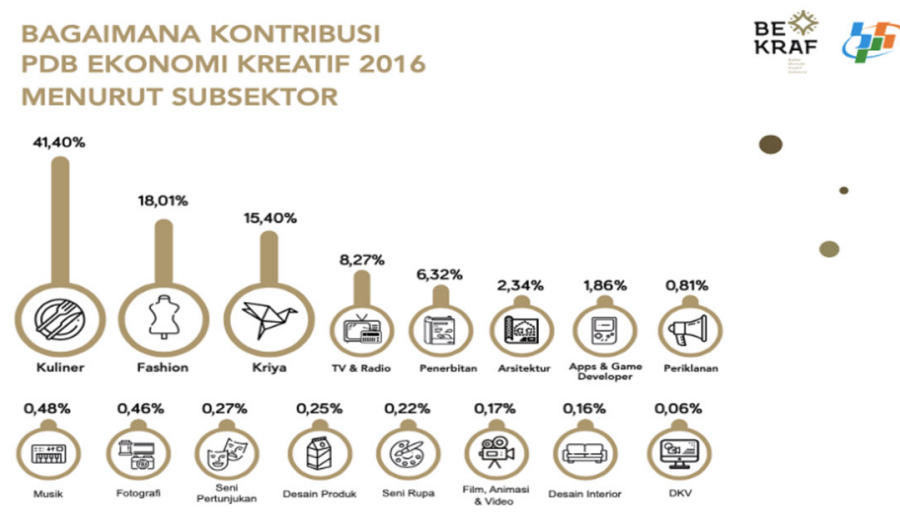

Gambar 1. Kontribusi Sub sektor Ekonomi Kreatif pada PDB Ekonomi Kreatif Tahun 2016 
Business Process Reengineering (BPR) adalah pemikiran ulang mendasar dan desain ulang radikal dari proses bisnis untuk mencapai peningkatan dramatis. Dengan mengukur kinerja saat ini melalui elemen biaya, kualitas, layanan dan kecepatan (Hammer dan Champy, 1993) dalam riset Giri dan Santoso (2020). Tujuan utama rekayasa ulang mencakup peningkatan produktivitas, pencapaian hasil yang luar biasa, konsolidasi berbagai fungsi, dan pengurangan aktivitas yang tidak perlu. Perlu pendalaman bahan referensi mengenai kajian ilmiah terkait manajemen operasional khususnya Business Process Reengineering (BPR) pada sektor publik termasuk instansi pemerintah, selain itu perlu juga diperdalam kajian rencana pengembangan program (Giri dan Santoso, 2020).

Ada empat strategi yang dilakukan dalam program ekonomi kreatif, yaitu terkait (1) kebijakan, (2) sisi penawaran), (3) sisi sisi permintaan dan (4) mempertemukan sisi penawaran dan sisi permintaan (Santoso, 2020). Dalam rangka memenuhi startegi inilah perlu dikembangkan platform ekspor sub sektor kuliner dari tinjauan dari model sistem inovasi dengan menggunakan model sisi supply - linkage - demand.

\section{Model Supply-Linkage-Demand (Tinjuan Sistem Inovasi)}

Suatu perusahaan dapat mempertahankan keunggulan kompetitif dengan memanfaatkan kemampuannya dalam melakukan inovasi. Inovasi adalah proses yang kompleks untuk menciptakan ide dan mengimplementasikan ide tersebut hingga menjadi produk/proses baru dan kemudian mengkomersialkannya (Tidd dan Bessant, 2009). Dalam mengelola inovasi, kapabilitas dan sumber daya perlu dikonfigurasi dengan benar, walaupun sulit. Hal ini dikarenakan ada banyak faktor yang dapat menghambat inovasi, seperti investasi yang berlebihan dalam melatih karyawan dalam keterampilan tertentu, di mana pengembalian investasi kurang dari yang diharapkan. Mungkin juga keahlian dan keterampilan staf dan tenaga kerja memerlukan pembaharuan agar mampu menyesuaikan dengan kondisi terkini yang semakin canggih.

Inovasi ialah sebagai suatu gagasan baru yang diterapkan untuk memprakarsai atau memperbaiki sebuah produk atau proses dan jasa (Santoso, Tjiptogoro et al, 2020). Inovasi merupakan bentuk penerimaan oleh pengguna dan masyarakat dari keberhasilan invensi, implementasi teknologi dan riset serta pengembangan. Salah satu bentuk untuk mentransformasikan perubahan nilai tersebut adalah dengan melakukan komersialisasi. Dalam pelaksanaan riil, proses transformasi tersebut tidak mudah dan tergolong kompleks karena perjalanan proses invensi suatu produk akan menghadapi sejumlah tantangan besar. Meskipun dapat menjadi sebuah hambatan, tantangan tersebut harus dihadapi untuk mencapai tujuan transformasi invensi menjadi inovasi hingga produk berhasil diterima oleh pasar. Proses tersebut lazim disebut dengan jurang/lembah kematian (Valley of Death). 


\section{METODE PENELITIAN}

\section{Metode Pengumpulan Data}

Pengumpulan data dilakukan melalui:

a. Wawancara dilakukan kepada informan kunci yaitu pakar, pengambil kebijakan terkait dengan kuliner dengan melakukan Focus Group Discussion (FGD) dan rapatrapat koordinasi baik secara virtual maupun non virtual.

b. Desk Literature dilakukan untuk mendapatkan data-data sekunder yang melengkapi data primer yang telah didapat melalui FGD/ rapat. Metode pengumpulan data dilakukan juga dilakukan melalui observasi (Santoso, 2010).

Penelitian dilakukan dengan pendekatan kualitatif. Peneliti memilih untuk menggunakan dua tipe informan, yaitu informan kunci dan informan pendukung. Informan kunci adalah informan yang mengetahui secara mendalam permasalahan yang sedang diteliti, sedangkan informan pendukung adalah informan yang ditentukan dengan dasar pertimbangan memiliki pengetahuan dan sering berhubungan baik secara formal maupun informal dengan para informan kunci. Informan kunci antara lain pejabat dari Kementerian Perdagangan, Kementerian Pariwisata dan Ekonomi Kreatif, Kementerian Luar Negeri, Kementerian Koordinator Bidang Kemaritiman dan Investasi. Sub sektor kuliner difokuskan pada pemetaan potensi ekspor bumbu dan kuliner Indonesia untuk ekspor. Elemen/ Variabel penelitian yang digunakan adalah sisi pasokan (Supply Side), Linkage (Intermediary Side), dan sisi Kebutuhan (Demand Side)

\section{Kerangka Pikir}

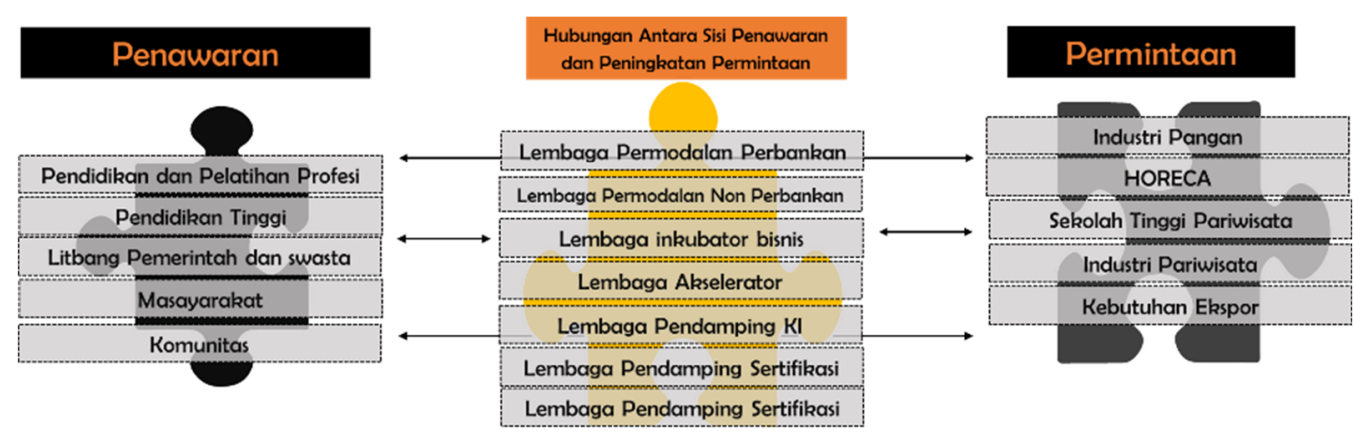

Gambar 2. Kerangka Penelitian

Analisis Supply Demand sangat tepat untuk diaplikasikan. Sebelum dapat menyusun model supply-demand linkage ini, perlu melakukan pemetaan permintaan, penawaran, hambatannya, dan juga linkage (intermediaries). Berikut merupakan gambaran penerapan konsep supply-demand linkage pada entitas ekosistem ekonomi kreatif sub sektor kuliner. Proses bisnis usaha kuliner dari hulu ke hilir, mulai dari ketersediaan bahan baku, proses penciptaan produk, pendistribusian, hingga penjualan sampai ke tangan konsumen. Melalui tahapan ini kita dapat melakukan identifikasi dan pemetaan terkait kondisi serta permasalahan yang dihadapi Indonesia untuk menuju bisnis kuliner yang mendunia. Selanjutnya, diperlukan sinergi antar pemangku kepentingan di setiap tahapan untuk menjamin kesinambungan dalam pencapaian tujuan. 


\section{HASIL DAN PEMBAHASAN}

Peningkatan aktivitas ekspor sub sektor kuliner merupakan sinergisitas dan goals dari beberapa stakeholder dan kementerian/ lembaga diantaranya adalah Kementerian Perdagangan, Kementerian Pariwisata dan Ekonomi Kreatif/ Badan Pariwisata dan Ekonomi Kreatif (Kemenparekraf/ Baparekraf), Kementerian Luar Negeri, Kementerian Koordinator Bidang Kemaritiman dan Investasi. Sinergisitas diwujudkan dalam Program bersama "Spice Up the World". Kementerian Koordinator Bidang Kemaritiman dan Investasi melalui Deputi Koordinasi Bidang Pariwisata dan Ekonomi Kreatif sedang mengkoordinasikan Rencana Aksi Kuliner Indonesia Spice Up The World 2021 Rencana Kerja Kementerian/ Lembaga untuk strategi kuliner Indonesia yang mengangkat tagline Indonesia Spice Up The World dengan 3 fokus (1) perluasan pemasaran produk bumbu/ pangan olahan dan rempah Indonesia terutama ke Afrika dan Australia; (2) pengembangan restoran Indonesia di luar negeri; dan (3) penguatan kuliner di dalam negeri atau destinasi gastronomi.

Beberapa kebijakan/ program/ kegiatan dari beberapa Kementerian/ Lembaga terkait diantaranya:

Kementerian Perdagangan untuk Mendorong Ekspor Indonesia di Tengah Pandemi Global

\section{Sisi Supply}

1. Penyederhanaan/ Pengurangan Lartas Ekspor dan Percepatan Proses Ekspor melalui National Logistics Ecosystem

2. Mempermudah dan mempercepat pelayanan penerbitan Surat Keterangan Asal (SKA) barang ekspor melalui penerapan affixed signature dan stamp

3. Mengusulkan insentif berupa asuransi atau kredit ekspor atau pembiayaan lainnya kepada Lembaga Pembiayaan Ekspor Indonesia/LPEI bagi eksportir terdampak Covid-19

4. Melaksanakan program pendampingan ekspor (Export Coaching Program) kepada eksportir

5. Meningkatkan daya saing produk ekspor UMKM dengan Memfasilitasi kegiatan showcase produk ekspor, melayani dan memfasilitasi informasi pasar bagi para eksportir nasional dan pembeli luar negeri melalui layanan InaExport.id

\section{Sisi Demand}

1. Melaksanakan Promosi dagang secara virtual

2. Mendorong pelaksanaan business matching secara virtual, termasuk melalui fasilitasi perwakilan perdagangan di luar negeri

3. Memaksimalkan keberadaan perwakilan perdagangan di luar negeri untuk mengawal keberlangsungan ekspor

\section{Strategi Penetrasi Pasar Di Masa Pandemi (Demand)}

Tabel 2. Strategi Jangka Pendek, Menengah, dan Panjang di Sisi Permintaan

\begin{tabular}{ll}
\multicolumn{1}{c}{ Jangka Pendek } & \multicolumn{1}{c}{ Jangka Menengah dan Panjang } \\
\hline Pemilihan Komoditas Ekspor Unggulan & $\begin{array}{l}\text { Berupaya mempertahankan pangsa pasar dengan } \\
\text { produk yang telah mendominasi di negara tujuan } \\
\text { ekspor }\end{array}$ \\
\hline Mengurangi Biaya dan Simplifikasi Biaya & \begin{tabular}{l} 
Peningkatan pangsa pasar produk yang potensial, \\
\hline
\end{tabular}
\end{tabular}




\begin{tabular}{ll}
\hline \multicolumn{1}{c}{ Jangka Pendek } & \multicolumn{1}{c}{ Jangka Menengah dan Panjang } \\
\hline $\begin{array}{l}\text { Prosedural Ekspor (Mengurangi komoditas wajib } \\
\text { laporan survey, Memfasilitasi SKA, Mengurangi }\end{array}$ & $\begin{array}{l}\text { yakni produk dengan nilai ekspor meningkat } \\
\text { dalam lima tahun }\end{array}$ \\
Larangan ekspor. & \\
\hline $\begin{array}{l}\text { Diplomasi Ekonomi dan Peningkatan Akses } \\
\text { Pasar, diantaranya diplomasi pengenaan tarif } \\
\text { preferensi, peningkatan akses pasar ekspor, } \\
\text { penguatan market intellegence di luar negeri. }\end{array}$ & $\begin{array}{l}\text { Evaluasi produk yang ekspornya turun dan } \\
\text { relaksasi ekspor impor bagi barang yang } \\
\text { dibutuhkan industri }\end{array}$ \\
\hline
\end{tabular}

Sumber: Hasil Olah Data

\section{Langkah Konkrit Kemendag dalam Pemulihan Ekspor Nasional Untuk Tingkatkan Perdagangan}

1. Fokus Pasar Dan Produk Ekspor: Fokus pada produk dengan pertumbuhan positif selama pandemi (makanan dan minuman olahan)

2. Penguatan Akses Pasar: Penguatan promosi Promosi Dagang: Pameran Trade Expo Indonesia Virtual Business Matching, Kegiatan Pencitraan, World Dubai Expo 2020, Promosi digital, Digitalisasi informasi ekspor melalui Inaexport.id, Penguatan Perwakilan Perdagangan RI di luar negeri dan melalui Market intelligence, Penyelesaian hambatan perdagangan

3. Penguatan UKM Orientasi Ekspor: Pelatihan ekspor dengan 3.424 peserta dan coaching program dengan target 38 pelaku usaha siap ekspor

4. Optimalisasi E-commerce: Pemanfaatan platform digital untuk perdagangan produk dalam negeri dan UKM berorientasi ekspor.

5. Kebijakan Ekspor \& Impor Untuk Tujuan Ekspor: Penguatan SKA: Permendag Nomor 39 tahun 2020 tentang Ketentuan Tata Cara Penerbitan e-SKA dengan penerapan affixed signature dan stamp

Terkait Program “Spice Up The World”: Produk Bumbu \& Kuliner Indonesia: Tabel 3. Tantangan \& Peluang Pengembangan Produk Bumbu dan Kuliner Indonesia

\begin{tabular}{|c|c|}
\hline Tantangan & Peluang \\
\hline $\begin{array}{l}\text { Pengembangan Pasar \& Produk: Rendahnya } \\
\text { produktivitas, Diversifikasi produk olahan, } \\
\text { Peningkatan nilai tambah produk (sertifikasi, } \\
\text { packaging, desain), Selera Konsumen } \\
\text { Internasional, Kurangnya promosi \& branding }\end{array}$ & $\begin{array}{l}\text { Ketersediaan Bahan Baku: SDA bahan } \\
\text { baku produk bumbu dan kuliner melimpah, } \\
\text { Alternatif bahan baku }\end{array}$ \\
\hline $\begin{array}{l}\text { Dampak COVID-19: Peningkatan biaya logistik, } \\
\text { Sulit sumber daya bahan baku, Perubahan pola } \\
\text { perdagangan global, E-commerce, Kerjasama } \\
\text { perdagangan tidak berjalan efektif selama } \\
\text { pandemi, Ancaman resesi ekonomi global }\end{array}$ & $\begin{array}{l}\text { Potensi Produk: Diversifikasi Produk } \\
\text { Pangan dan Bumbu, Global value chain, } \\
\text { Potensi tanaman perkebunan dan } \\
\text { holtikultura tiap daerah }\end{array}$ \\
\hline $\begin{array}{l}\text { Tantangan Industri: Manajemen pasca panen, } \\
\text { Kurangnya kebaruan atau inovasi teknologi } \\
\text { pangan, Logistik }\end{array}$ & $\begin{array}{l}\text { Permintaan Global: Life style: Pola } \\
\text { konsumsi dan diet untuk kesehatan (organic } \\
\text { and heath food, convenience food), } \\
\text { Sustainable food system }\end{array}$ \\
\hline $\begin{array}{l}\text { Tantangan Pasar Global: Food Safety, Akses } \\
\text { pasar, Sertifikasi, Organik \& Halal, Izin Edar, } \\
\text { Sustainability, Traceability dan Transparancy, } \\
\text { Kontinuitas \& on-time delivery }\end{array}$ & $\begin{array}{l}\text { Tren Digitalisasi: Pemanfaatan e-commerce } \\
\text { untuk pemasaran dan penjualan produk } \\
\text { Kompetensi SDM: Regenerasi SDM } \\
\text { Pertanian Generasi Milenial dan SDM } \\
\text { Pengolahan Mamin memanfaatkan inovasi } \\
\text { teknologi }\end{array}$ \\
\hline
\end{tabular}

Sumber: Hasil Olah Data 


\section{Rencana Aksi:}

Market Intelligence: Mendata potensi market \& syarat ekspor

Gastro Diplomacy: Membuat panduan Gastro Diplomacy ke targer pasar, terutama negara-negara di Afrika dan Australia berdasarkan Market Intelligence 2021.

Untuk kemajuan sub sektor kuliner Kemenparekraf/ Baparekraf turut serta dalam semua bentuk promosi, publikasi, aktivasi luring, mengangkat program Food Startup Indonesia, bedah desain kemasan untuk mendukung Spice Up The World. Menetapkan menu wajib untuk promosi kuliner dan bumbu Indonesia yang dapat menjadi standar untuk memudahkan kampanye promosi. Food Startup Indonesia menghadirkan sebuah wadah yang dapat mendukung percepatan pertumbuhan ekonomi kreatif kuliner di Indonesia. Sedangkan Kementrian Luar Negeri (Kemenlu) tengah menggerakkan program Gastro Diplomasi yang merupakan program untuk memperkenalkan cita rasa kuliner Indonesia pada dunia. Kementrian luar negeri tengah mengarahkan untuk membuka foodcourt untuk memperkenalkan kuliner Indonesia atau promosi meal package untuk anak-anak sekolah di luar negeri.

Tinjauan Sistem Inovasi dengan Model Supply - Linkage - Demand untuk mengakselerasi Pengembangan Platform Ekspor Sub Sektor Kuliner dengan percontohan Program Bersama "Spice Up The World” diformulasikan sebagai berikut:

Tabel 4. Penguatan Sisi Demand (Permintaan)

\begin{tabular}{lll}
\hline \multicolumn{1}{c}{ Objek } & \multicolumn{1}{c}{ Variabel } & \multicolumn{1}{c}{ Instrumen Kebijakan/ Program/ Kegiatan } \\
\hline $\begin{array}{l}\text { Inovasi bagi Pelaku } \\
\text { usaha }\end{array}$ & Tingkat Persaingan & \\
\hline & & Deregulasi sistem persaingan pasar \\
\hline & Akses Pasar & $\begin{array}{l}\text { Keberpihakan pemerintah dalam mengakses produk } \\
\text { domestic }\end{array}$ \\
& \\
& & $\begin{array}{l}\text { Dukungan infomasi tentang perkembangan pasar lokal } \\
\text { dan ekspor }\end{array}$ \\
\hline & Aliran Permodalan & $\begin{array}{l}\text { Penyediaan matchmaking, akses permodalan untuk } \\
\text { startup/ pelaku usaha kreatif }\end{array}$ \\
&
\end{tabular}

\section{Sumber: Hasil Olah Data}

Tabel 5. Penguatan Sisi Linkage

\begin{tabular}{lll}
\hline \multicolumn{1}{c}{ Objek } & \multicolumn{1}{c}{ Variabel } & \multicolumn{1}{c}{ Instrumen Kebijakan/ Program/ Kegiatan } \\
\hline $\begin{array}{l}\text { Penguatan Hub } \\
\text { Pemasok-Pengguna }\end{array}$ & Jaringan Kerja sama & Memperkuat distribusi bumbu/ rempah \\
\hline & & $\begin{array}{l}\text { Forum Komunikasi antara industry, Perguruan Tinggi, } \\
\text { dan Lembaga Penelitian dan Pengembangan }\end{array}$ \\
\hline & & Inventarisasi regulasi pendukung \\
\hline & Informasi dan & $\begin{array}{l}\text { Sinergi Promosi Lintas K/L (Penyediaan informasi } \\
\text { inovasi) }\end{array}$ \\
\hline Promosi & Dukungan pendampingan pembiayaan dan ekspor \\
\hline & Alih Teknologi & $\begin{array}{l}\text { Dukungan pendampingan ijin edar di dalam dan luar } \\
\text { negeri } \\
\text { Memberikan perlindungan Kekayaan Intelektual (KI) }\end{array}$ \\
\end{tabular}




\begin{tabular}{|c|c|c|}
\hline Objek & Variabel & Instrumen Kebijakan/ Program/ Kegiatan \\
\hline & & $\begin{array}{l}\text { dan Kekayaan Intelektual Komunal (KIK atau Indikasi } \\
\text { Geografis) }\end{array}$ \\
\hline
\end{tabular}

Sumber: Hasil Olah Data

Tabel 6. Penguatan Sisi Supply (Penawaran)

\begin{tabular}{lll}
\hline \multicolumn{1}{c}{ Objek } & \multicolumn{1}{c}{ Variabel } & \multicolumn{1}{c}{ Instrumen Kebijakan/ Program/ Kegiatan } \\
\hline $\begin{array}{l}\text { Penguatan } \\
\text { Penawaran }\end{array}$ & Penguatan Hasil & Promosi Jaringan Pelayanan: \\
& Inovasi & $\begin{array}{l}\text { Membuat Panduan Gastro diplomasi target pasar Afrika, } \\
\text { Australia }\end{array}$ \\
\hline & & Memperkuat Penawaran bahan baku rempah \\
\hline Innovation & Mengembangkan standar restoran \\
Capacity & Inovasi Supply Chain & Menguatkan Nation Branding seluruh restoran di luar \\
& & negeri \\
\hline
\end{tabular}

\section{KESIMPULAN DAN SARAN}

Untuk dapat melakukan ekspor, pelaku usaha kreatif dapat bersinergi dengan Program Kolaborasi yang dilakukan oleh berbagai stakeholder yang dikoordinasikan oleh Pemerintah. Penelitian ini dilakukan secara partisipatori dan menggunakan Model Supply -Linkage-Demand yang lazim digunakan pada tinjauan sistem inovasi, dimana masingmasing elemen penguatan sisi permintaan, penguatan sisi pasokan dan penguatan sisi linkage mempunyai varibel dan instrumen kebijakan berupa program/ kegiatan. Instrumen kebijakan/ program/ kegiatan ini merupakan rekomendasi (usulan) model yang bisa diimplementasikan dalam Pengembangan Platform Ekspor Sub Sektor Kuliner yang dalam penelitian ini diambil dari fokus penelitian Program Spice Up The World, yang selanjutnya didetilkan menjadi rencana aksi dari masing-masing stakeholder.

Implikasi penelitian: Model bisa diadopsi sebagai platform Ekspor untuk pihakpihak yang berkepentingan dan harapannya dengan karya tulis ini semakin banyak pelaku usaha ekonomi kreatif mikro kecil dan menengah sub sektor kuliner bisnis kuliner yang berani untuk memasarkan produknya ke luar negeri.

\section{DAFTAR PUSTAKA}

Andrea, Giri; Sugeng Santoso (2020). Improving Economy of the Community Based on Sustainable Tourism and Creative Economy through Business Process Re-Engineering (BPR) With Geopark Development in Lebak Regency Banten Province, International Journal of Innovative Science and Research Technology, Volume 5, Issue 1, January-2020.

Santoso, Sugeng; Nurzaki, Alfi; Santoso, Arga; Benawan, Chano; Wahyudin, Didin (2020). Kinerja PT. PLN Unit Induk Distribusi Jakarta Raya Dengan Supply Chain Operation Reference, Jurnal Distribusi, Vol. 8, No. 2, Halaman 255 s.d 266, September 2020, Fakultas Ekonomi dan Bisnis, Universitas Mataram, http://dx.doi.org/10.29303/distribusi.v8i2.136 
Ari Ana, Fatmawati dan Santoso (2020). Penguatan Rantai Nilai Pariwisata Sebagai Strategi Pengembangan Kawasan Kota Tua Jakarta Menjadi Kawasan Wisata Ramah Muslim, Jurnal Ilmiah Manajemen dan Bisnis, Fakultas Ekonomi dan Bisnis, Universitas Mercu Buana, Vol. 6 (3), hal. 284-304, Nov. 2020. https://doi.org/10.22441/jimb.v6i3.9825

Dumilah, Dewi Retno; Moh. Komarudin; Rian Ubaidillah; Sulastri Siagian; Sugeng Santoso (2021). Peran Ekonomi Kreatif Dalam Meningkatkan Industri Pariwisata Di Seaworld Ancol, Jurnal Master Pariwisata (JUMPA) Volume 7, Nomor 2, Januari 2021.

Endri; Afriapollo Syafarudin; Sugeng Santoso; Erna S. Imaningsih; Titing Suharti; Rachmatullaily T. Rinda (2020). Consumption Behavior Patterns of Generations Y Halal Products In Indonesia, Academy of Entrepreneurship Journal, Volume 26, Issue 2, 2020.

Santoso, Sugeng; Tjiptogoro Dinarjo Soehari; Yoce Aprianto; Dicky Andrean; Henny (2020). Value Creation In Fisheries Supply Chain As A Role Model For Fish Protein Hydrolyzate Cluster Development, Jurnal Rekayasa Mesin V11 N3, artikel 12, pp. 401-407. https://doi.org/10.21776/ub.jrm.2020.011.03.12

Santoso, Sugeng (2020). Optimizing Access to Financial Capital of Creative Economy for Startups Towards Global Competitiveness, Jurnal BECOSS (Business Economic, Communication, and Social Sciences), Vol.2 No.2 May 2020: 13-21.

Santoso, Sugeng (2010). Penerapan Metode Multi Dimensional Scaling (MDS) Dalam Perencanaan Formulasi Strategi Pemasaran Supermarket Hero Malang, Jurnal Teknik Industri, Vol.1 No.1, Hal. 60 - 70. https://doi.org/10.22219/JTIUMM.Vol1.No1.60-70.

Santoso, Sugeng (2010). Model Logit (Logistic Regression) sebagai Model Probabilitas Linier Alternatif Dalam Contoh Aplikasi di Teknik Industri, Jurnal Teknik Industri, Vol.2 No.1, Hal. 59 - 64. https://doi.org/10.22219/JTIUMM.Vol2.No1.59-64. 